\section{Ronald Edward Bibby}

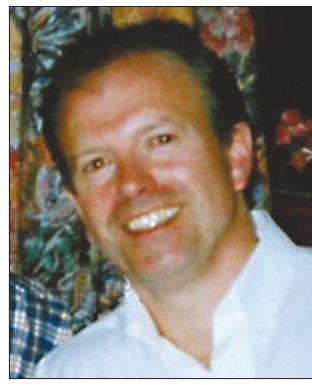

Ron Bibby died on Sunday 22 May 2005 at the age of 54, following a long battle with cancer, conducted in Ron's typically courageous manner. Ron was born and raised in Liverpool, but left his home city in 1969 and travelled to the distant northern town of Dundee to undertake dental training.

Ron's undergraduate life was a tribute to his 'work hard, play hard' style, which included surprising his friends by taking a year out after third year BDS to complete a B.Med.Sc. Ron was an exemplary polymath; he partied with the best of us, studied and examined better than most of us and had a keen, questioning interest in a wide range of pursuits.

After graduation, Ron worked in general practice in Dundee and during this period he married Norma. Once he had gained his M.Med.Sc. in 1977, they moved to South Africa, where Ron gained his orthodontic degree in 1980 . He went on to teach orthodontics at the University of the Western Cape and was appointed Professor of Orthodontics. As his professional standing grew, so did his family. When the Bibby family returned to the UK, friends not only re-established contact with Ron and Norma, but were delighted to meet Ross, Clare and Jane.

\section{He was never afraid to challenge; always respectful and respected.}

Ron and Norma settled happily into the lovely town of Auchterarder, establishing friendships and becoming deeply embedded in the town and their local church. Ron's 'play hard' attitude led him to complete the gruelling Highland Cross event several times, raising funds with his team for charities close to their hearts.

Professionally, Ron established a well respected orthodontic practice in Perth, which has grown in size and reputation over the years. He also maintained an interest in research in his field and presented at many international conferences. To the end he was refining and compiling work for his $\mathrm{PhD}$.

We send our sympathy to Norma, Ross, Clare and Jane. As well as his dear family, Ron is survived by his mother, Alice and his two sisters, Beryl and Alison. Ron was a good man and honest friend. Those of us who knew him will remember his wide, engaging smile and thoughtful use of words. He was never afraid to challenge; always respectful and respected. Our prayers are with Norma and her children as their lives adjust to bear their loss.

J. Willmott

\title{
Norman Penman Thomson
}

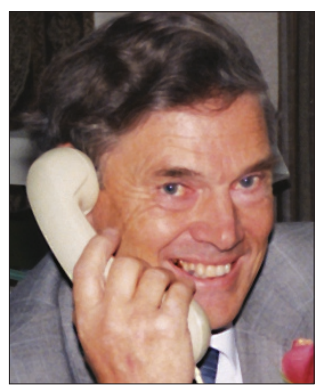

Norman Thomson died suddenly on 22 May 2004, aged 70. He was born and raised in Edinburgh, attending Daniel Stewart's College then entering Edinburgh Dental Hospital and School in 1950, where he met his wife Christine. Norman's first position was in general practice in Woking but in 1960 he returned to Lothian. He joined Midlothian County Council and was based in Penicuik until 1974.

Following a major re-organisation in 1974 and the creation of the Community Dental Service, Norman was appointed District Dental Officer for North Lothian, a post he held until his retirement in 1988. In this post Norman saw the Community Dental Service develop a provision for all in the community, as well as provide extensive oral health education and preventive care for children.

One of Norman's lasting achievements was the establishment of the Emergency Dental Service in October 1977, based in the Western General Hospital, Edinburgh. In the first three months 504 patients were treated. In the year that Norman retired, 1988, six thousand patients were seen. Norman put much personal energy into making this service a success.

\section{One of Norman's lasting achievements was the establishment of the Emergency Dental Service in Edinburgh...}

Inevitably, as the service was only open in the evenings and at weekends, this intruded into his personal life, including family holidays. He had a very understanding family!

Norman lived a full life in his retirement, retaining keen interests in photography, travel, golf, skiing, country dancing and Scottish fiddle music. In the mid 1990s Norman was able to take a number of trips on a traditional steam powered Clyde Puffer, of the type sailed by Para Handy.

Norman is sadly missed by his family; Christine, daughters Fiona, Helen and Susie and his six grandchildren, and by many former colleagues with whom he kept in touch. One of Norman's friends and colleagues wrote: 'We are going to be much poorer without Norman but his Christian faith and his positive and inspirational attitude to life's challenges will stand us in good stead.'

R. Naysmith 